\title{
Assessment of Undiscovered Oil and Gas Resources of the Azov-Kuban Basin Province, Ukraine and Russia, 2010
}

\author{
The U.S. Geological Survey, using a geology-based assessment methodology, estimated mean volumes of technically \\ recoverable, conventional, undiscovered petroleum resources at 218 million barrels of crude oil, 4.1 trillion cubic feet of \\ natural gas, and 94 million barrels of natural gas liquids for the Azov-Kuban Basin Province.
}

\section{Introduction}

The U.S. Geological Survey (USGS) estimated technically recoverable, conventional, undiscovered oil and gas resources of the Azov-Kuban Basin Province in Ukraine and Russia as part of a program to estimate petroleum resources for priority basins around the world. The province encompasses about 161,000 square kilometers, northeast of the Black Sea (fig. 1). This assessment was based on published geologic information and on commercial data from oil and gas wells and fields, and field production records. The USGS approach is to define total petroleum systems and assessment units, and assess the potential for undiscovered oil and gas resources.

\section{Total Petroleum Systems and Assessment Units}

One total petroleum system (TPS), the Mesozoic-Cenozoic Composite, was defined for the Azov-Kuban Basin Province (table 1) to include petroleum source rocks ranging in age from Jurassic through lower Neogene. One assessment unit (AU) was defined geologically within the TPS that encompasses the entire
province-Foredeep and Foreland Slope (figs. 1 and 2). A second AU possibly containing continuous accumulations, Foredeep Tight Gas, was identified based on an assumed overpressured section in the basin center, but was not quantitatively assessed in this study.

Major source rocks are mudstones within the middle-upper Eocene and Oligocene-lower Miocene stratigraphic section (Robinson and others, 1996). Potential source rocks include Lower Cretaceous and Lower to Middle Jurassic mudstones, and possibly Upper Jurassic subsalt black mudstones. Cenozoic source rocks at present are in the oil window; maturation was probably reached in late Miocene to Pliocene time when the greatest amount of sediment was deposited. Older source rocks at present are overmature in oil generation, having matured in the Late Cretaceous to Paleogene. Most known recoverable crude oil was discovered in Paleogene-Neogene reservoirs (down to a depth of 4,600 m) and most of the known recoverable natural gas was discovered in Cretaceous reservoirs (down to a depth of $6,100 \mathrm{~m}$ ), although Cenozoic reservoirs also contain significant quantities of natural gas (IHS Energy, 2009). Seal rocks include Oligocene-Miocene mudstones, intraformational mudstones, and Upper Jurassic evaporites, as

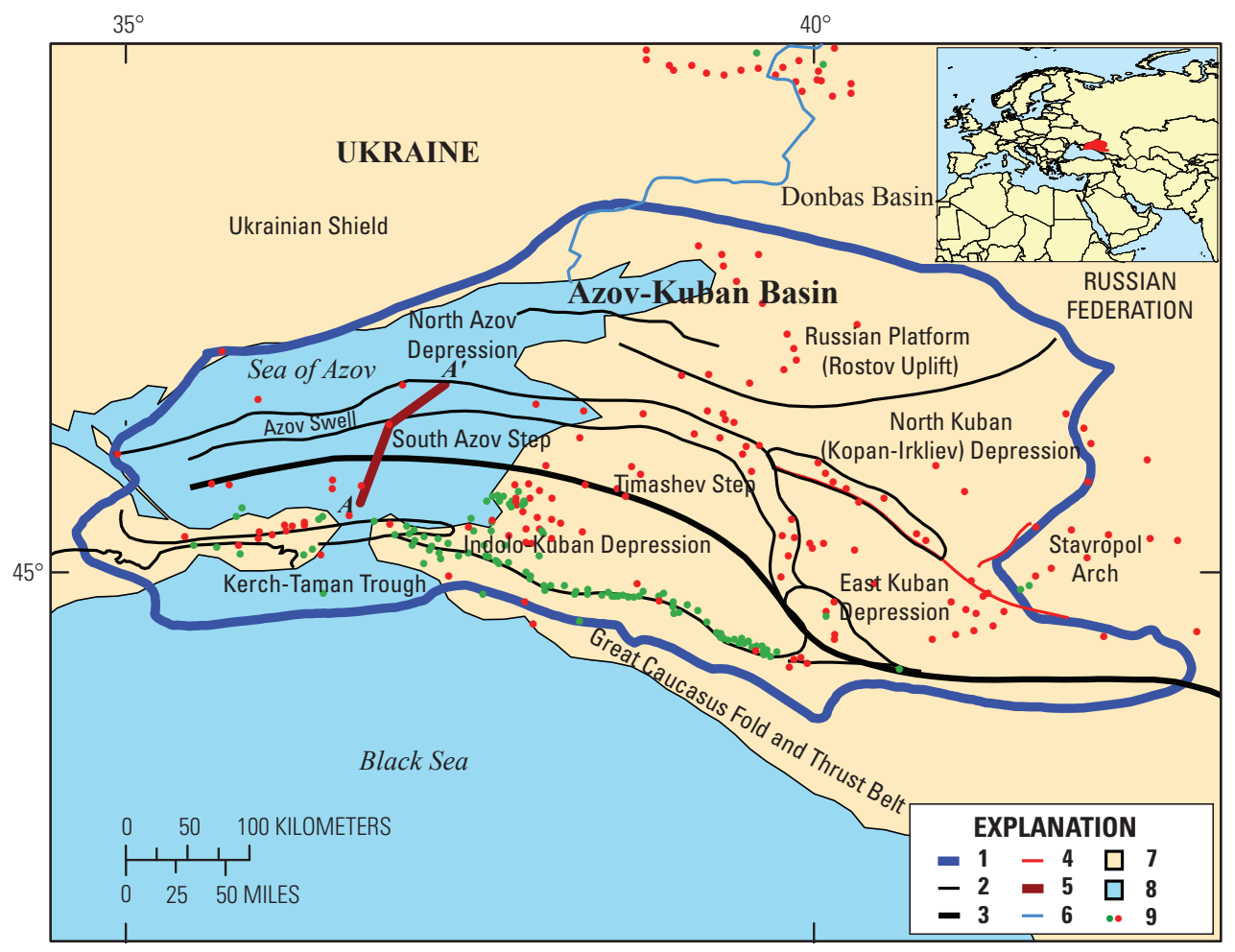

Figure 1. Generalized map showing major geologic features and structures, oil and gas fields, and the location of a geologic cross section (fig. 2) used in the assessment of the Azov-Kuban Basin Province. Field data from IHS Energy (2009); geologic province boundary from Persits and others (1998); structural features from Gajuk and others (2008), Khain and others (2005), Lavrenova and Kruglyakova (2010), Meisner and others (2009), Solov'yev and others (2010), and Yudin (2007). Explanation: 1 , geologic province and total petroleum system boundary; 2 , boundary of structural domain; 3 , scarp edge; 4, fault; 5 , geologic cross section shown in fig. $2 ; 6$, country boundary; 7, land; 8, water; 9 , oil (green)/ gas (red) field centerpoint. 
Table 1. Azov-Kuban Basin Province assessment results (technically recoverable, conventional undiscovered resources). [MMB, million barrels; BCF, billion cubic feet. Results shown are fully risked estimates. For gas fields, all liquids are included under the natural gas liquids (NGL) category. F95 denotes a 95-percent chance of at least the amount tabulated. Other fractiles are defined similarly. Fractiles are additive under the assumption of perfect positive correlation. TPS, total petroleum system; AU, assessment unit. Gray shading indicates not applicable]

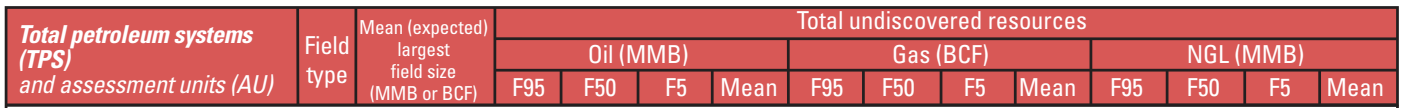

\begin{tabular}{|c|c|c|c|c|c|c|c|c|c|c|c|c|c|c|}
\hline \multicolumn{15}{|c|}{ Azov-Kuban Basin Province, Mesozoic-Cenozoic Composite TPS } \\
\hline Foredeep and Foreland & Oil & 35 & 97 & 204 & 391 & 218 & 114 & 263 & 556 & 290 & 2 & 4 & 9 & 4 \\
\hline Slope AU & Gas & 574 & & & & & 1,666 & 3,534 & 6,866 & 3,803 & 38 & 83 & 167 & 90 \\
\hline $\begin{array}{l}\text { Total undiscovered } \\
\text { petroleum resources }\end{array}$ & & & & & & 218 & & & & 4,093 & & & & 94 \\
\hline
\end{tabular}

well as tar in shallow accumulations. Identified traps are formed by structures associated with (1) mud diapirs, (2) compressional structures (faults and anticlines), (3) basement-related anticlines, and (4) drapes over basement highs and inverted Triassic rifts. Jurassic and Cretaceous reef facies also provide traps.

The future potential for undiscovered conventional oil and gas accumulations is in structures associated with mud diapirs, deep $(>3.5 \mathrm{~km})$ compressional and basement-related structural traps, and stratigraphic traps, which previously have not been fully exploited. Potential stratigraphic traps include upper Paleogene-Neogene slope and basin gravity-flow deposits, upper Neogene fluvial deposits, and reefs and reef facies in Cretaceous-lower Paleogene and Upper Jurassic subsalt intervals. Offshore areas are less explored than onshore, and therefore have greater potential for undiscovered accumulations.

\section{Assessment Results}

Estimates of volumes of technically recoverable, conventional, and undiscovered oil and gas resources are shown in table 1. No attempt was made to estimate economically recoverable resources because it is beyond the scope of this study. The mean volumes of undiscovered petroleum are approximately 218 million barrels (MMB) of crude oil, 4,093 billion cubic feet (BCF) of natural gas (290 BCF of associated and dissolved natural gas and $3,803 \mathrm{BCF}$ of nonassociated natural gas), and $94 \mathrm{MMB}$ of natural gas liquids.

\section{References Cited}

Gajduk, V.V., Gubarev, M.V., Proshlyakov, S.L., Derduga, A.V., Lavrov, A.I., and Mollaev, Z.Kh., 2008, Perspektivy neftegazonosnosti shel'fa Azovskogo moray (Prospects of the Azov Sea shelf oil-and-gas content): Neftyanoye Khozyaystvo (Oil Industry), v. 6, p. 26-30. [In Russian.]

IHS Energy, 2009 [includes data current through October 2009], International exploration and production database: Englewood, Colo., IHS Energy.

Khain, V.E., Levin, L.E., and Polyakova, I.D., 2005, Petroleum potential of deep Oligocene-Miocene basins in southern Russia: Doklady Earth Sciences, v. 404, no. 7, p. 979-981.

Lavrenova, E., and Kruglyakova, M., 2010, Specific features of temporal and spatial distributions of light hydrocarbons in the Sea of Azov: Geo-Marine Letters, v. 30, p. 249-260.

Meisner, A., Krylov, O., and Nemčok, M., 2009, Development and structural architecture of the Eastern Black Sea: The Leading Edge, v. 28, no. 9, p. 1046-1055.

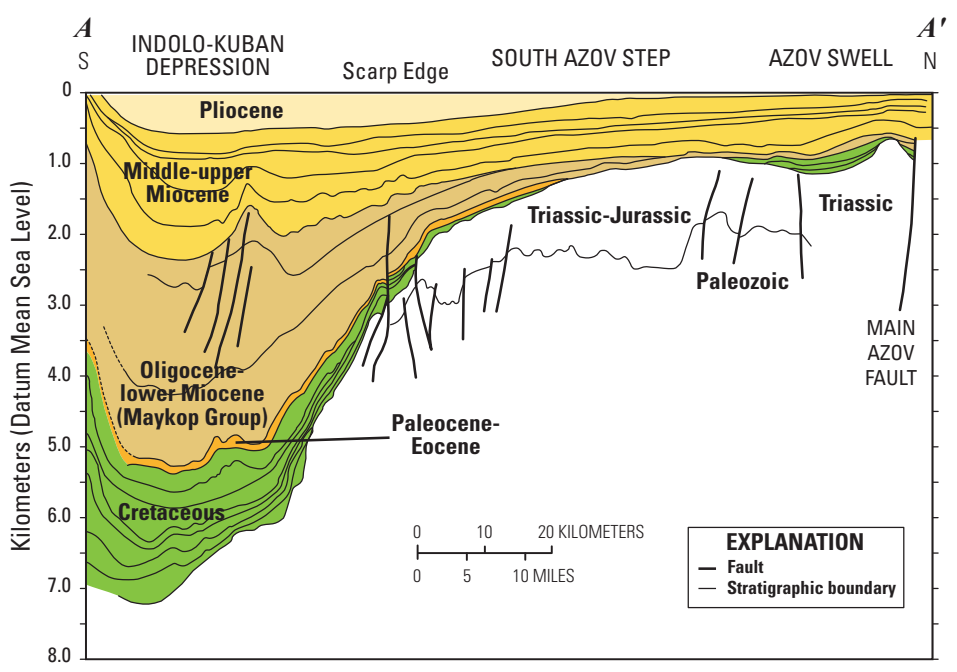

Figure 2. Geologic cross section for the Azov-Kuban Basin. See figure 1 for location. Modified from Gajuk and others (2008).

Persits, F.M., Ulmishek, G.F., and Steinshouer, D.W., 1998, Map showing geology, oil and gas fields, and geologic provinces of the Former Soviet Union: U.S. Geological Survey Open-File Report 97-470E, CD-ROM.

Robinson, A.G., Rudat, J.H., Banks, C.J., and Wiles, R.L.F., 1996, Petroleum geology of the Black Sea: Marine and Petroleum Geology, v. 13, no. 2, p. 195-223.

Solov'yev, B.A., Levshunova, S.P., Podkorytov, N.G., and Yevsyukova, I.I., 2010, Perspektivy poiskov nefti i gaza v VostochnoKubanskoy vpadine (Prospect search for oil and gas in the Eastern Kuban Depression): Geologiya Nefti i Gaza, v. 2010, no. 1 , p. 8-15, in Russian.

Yudin, V.V., 2007, Structural-geodynamic map of the Black and Caspian Seas region [abs.]: European Association of Geoscientists and Engineers Regional Meeting, Petroleum Geology and Hydrocarbon Potential of Caspian and Black Sea Regions, 6-8 October 2008, Baku, Azerbaijan, Abstract A13.

\section{For Further Information}

Publications detailing the geology and the methodology for the Azov-Kuban Basin Province and assessment results are available at the USGS Central Energy Resources Science Center web site, http://energy.cr.usgs.gov/oilgas/.

\section{Azov-Kuban Basin Province Assessment Team}

T.R. Klett (tklett@usgs.gov), Christopher J. Schenk, Ronald R. Charpentier, Michael E. Brownfield, Janet K. Pitman, Richard M. Pollastro, Troy A. Cook, and Marilyn E. Tennyson. 